\title{
Highway Infrastructure, Protected Areas, and Orchid Bee Distribution and Conservation in the Brazilian Amazon
}

\author{
Marcio L. Oliveira ${ }^{*}$, John C. Brown ${ }^{2}$, Marcelo P. Moreira ${ }^{3}$ \\ ${ }^{1}$ Instituto Nacional de Pesquisas da Amazônia, Coordenação de Biodiversidade, Manaus, Brazil \\ ${ }^{2}$ Department of Geography and Atmospheric Science, University of Kansas, Lawrence, USA \\ ${ }^{3}$ Fundação Vitória Amazônica, Manaus, Brazil \\ Email: ^mlolivei@inpa.gov.br
}

How to cite this paper: Oliveira, M.L., Brown, J.C. and Moreira, M.P. (2017) Highway Infrastructure, Protected Areas, and Orchid Bee Distribution and Conservation in the Brazilian Amazon. Journal of Environmental Protection, 8, 923-939. https://doi.org/10.4236/jep.2017.88058

Received: June 1, 2017

Accepted: July 25, 2017

Published: July 28, 2017

Copyright $\odot 2017$ by authors and Scientific Research Publishing Inc. This work is licensed under the Creative Commons Attribution International License (CC BY 4.0).

http://creativecommons.org/licenses/by/4.0/

\begin{abstract}
Scientists regularly lament that development and habitat destruction in once isolated and distant areas are promoting species extinction before species can even be known by science. In the Brazilian Amazon, the government's Plan for Growth Acceleration in part involves major improvements and expansion of highways. Such infrastructure has long been linked to the main causes of deforestation in this region. It is essential for scientists to assess where to target biodiversity collections in relation to the location of road development and existing protected areas. The objective of this study was to amass all of the records of occurrence of orchid bees in digital form, in order to obtain a spatial picture of our knowledge thus far and to make recommendations about priority areas for future collections and the role of protected areas in species conservation. The collection data used for this study come from various collection efforts, and were also gathered from the literature. The collection data were then imported into a Geographic Information System, making it possible to integrate other spatial data layers such as highways, conservation units, indigenous lands and forest cover. Results show a major need for collections along the BR 163 and BR 230 highways, heavily deforested areas with few conservation units. We suggest the creation of conservation units and recommend that abandoned areas be allowed to remain fallow as a way to help save additional biodiversity in the area of influence of these two main highways.
\end{abstract}

\section{Keywords}

Amazonia, Collections, Deforestation, Euglossini, Roads 


\section{Introduction}

Road construction, improvements, and expansion are bringing frontier regions of the world into the global economic sphere at an accelerated pace. With this comes rapid habitat destruction and fragmentation that negatively impacts biodiversity, and biodiversity experts have long lamented that species are going extinct before science even has a chance to describe or study them. With time running short, it is essential to target the collection of species data in areas where there are spatial gaps in collections and where we know road development is likely to occur. We also must consider the role protected areas are playing in protecting biodiversity in relation to road development. The information for all of this exists, and if properly assembled in a GIS (Geographic Information System), scientists could more efficiently target collection efforts and the evaluation of the role of protected areas in species conservation. Unfortunately, species occurrence information is often not readily available in digital form. Rather, much of that information is contained only on specimen tags in museums. Efforts by organizations such as the GBIF (Global Biodiversity Information Facility) in recent years are emblematic in making millions of species occurrence records digitally available. GBIF serves $>6.4 \times 108$ occurrence records for $>1.6 \times 106$ species, but it is an ongoing effort to fill gaps, address biases and make the data more complete [1] [2]. Among the groups least represented in GBIF are insects $(<8 \%$ of the total set of records), despite their high diversity and ecological importance.

Among the insects, bees are considered excellent pollinators, involved in the pollination of close to $60 \%$ of the approximately 1500 species of human cultivated plants [3]. In addition, they comprise one of the most species rich groups in the world; in Brazil we have 1778 species already identified [4]. Orchid bee males (Apidae: Euglossini) are important pollinators of orchids and other families of plants in the Neotropics, pollinating close to $10 \%$ of the orchid species [5].

There is mounting evidence that environmental change is contributing to the decline in pollinator abundance and diversity worldwide, with serious consequences for the diversity and survival of wild and cultivated plants [6] [7] [8], and there are many studies that document the link between highways and environmental change in the Brazilian Amazon [9]-[23]. Major transportation axes were opened in the Amazon by the Brazilian government in the 1970s with the aim of colonizing the region. Most of these highways have deteriorated over the years for lack of maintenance. Now, the federal government is in the process of improving various major highways in the region via an effort called the PAC (Plan for Growth Acceleration). Highways with especially strategic importance are the BR-319 (Manaus-Porto Velho), BR-163 (Cuiabá-Santarém) and the TransamazônicaBR-230 (Itaituba-Marabá segment), and these stretches of road are the focus of our study. The impacts on forests are estimated to reach to $100 \mathrm{~km}$ on both sides of the margins of major highways in the Amazon, according toSustainable Amazon Plan [24], with more than 2/3 of deforestation occurring in an area within $50 \mathrm{~km}$ of paved roads [20]. Impacts are not restricted, however, to 
these official highways. Impacts can also extend from unofficial roads built by miners and loggers [24]. According to [25], such roads allow for illegal land grabbing on public lands, and as a consequence, land conflict results; this in turn provokes deforestation, burning, and predatory logging. There are estimates that unofficial roads reach a total length of $170,000 \mathrm{~km}$, or nearly $70 \%$ of official road length [23]. In general, a highly fragmented landscape has formed as a result, and our knowledge about the biodiversity in the areas along these roads is scarce or non-existent. Furthermore, in fragmented landscapes, there is often diminished gene flow between populations, which can reduce diversity over time. Depending on the size of the fragment, level of conservation, time, and isolation, the consequences for biodiversity can be quite severe.

The current study was motivated by the need for more digitally available species occurrence data to help address the imminent threat that road development, and resulting habitat destruction, present to bees. The study's objective was to model how to aggregate digital and non-digital species records into a fully georeferenced dataset, allowing for exploratory spatial data analysis in a GIS of the distribution of species occurrences, road development, and the role protected areas play in the conservation of these species. We do this for one group of bees, orchid bees, which have been collected in the Brazilian Amazon for more than a century and are the principal pollinators of many orchids and other plants sensitive to deforestation.

\section{Material and Methods}

Records came from a variety of digital and non-digital collections and literature, and had varying degrees of geographic resolution for collection sites. To standardize the information, we convert all records to a decimal coordinate system. When specific coordinates were missing, we used the tool "geoLoc" available at Species Link (http://splink.cria.org.br/geoloc?criaLANG=pt), to get the geographic coordinates of the location cited on specimens' labels. By inputting information about localities, names of cities, states, and/or counties, geoLoc returns an absolute location, pulling information from servers at the following institutions: IBGE (The Brazilian Institute of Geography and Statistics), SpeciesLink/Fapesp (São Paulo Research Foundation), and GEOnet.

Most of the material for this study had already been identified by the first author. Information from the catalogs of a number of other collections was included in the dataset, even though they were not consulted in loco. Finally, a small part of the species names and the collection locations was obtained from the literature, predominately from studies carried out by other specialists, or the material was identified by them.

The following collections provided records of orchid bees collected in the Brazilian Amazon:

Bee Collection of the University of Kansas

Collection of the Instituto Oswaldo Cruz

Departamento de Zoologia da Universidade Federal do Paraná

Faculdade de Filosofia, Ciências e Letras de Ribeirão Preto 
Insect Collection of the University of Cornell

Instituto Nacional de Pesquisas da Amazônia

Museu Integrado de Roraima

Museu Nacional do Rio de Janeiro

Museu Paraense Emílio Goeldi

United States National Museum (Natural History)

Universidade Federal de Ouro Preto

Universidade Federal doAcre

AdolphoDucke, from the end of the $19^{\text {th }}$ century through the first quarter of the $20^{\text {th }}$ century, made the first known collections of orchid bees in the Brazilian Amazon. In that period, he collected mainly female orchid bees while they visited flowers, since the discovery of using artificial baits to attract males would only occur decades later [26]. Thus, the collections consulted for this paper cover all of this period of collecting in the Amazon, given that we included collections by Ducke from the Goeldi Museum up to those collected during the assembly of this paper, whose data were sent to us by collaborators.

The following data layers were gathered for use in a GIS: political boundaries of the states of the Legal Amazon of Brazil, highways, protected areas (Conservation Units and Indigenous Lands) and forest coverage. These data were obtained from the Brazilian Ministry of the Environment via ftp download from the FVA (Vitória Amazônica Foundation). A shape file of highways (existing, under improvement, and planned) was downloaded from a federal government website (http://www.transportes.gov.br/index/conteudo/id/36604, on 07/13/2011). Files showing deforestation in the study area were downloaded from INPE/ PRODES (http://www.dpi.inpe.br/prodesdigital/prodes.php, on 01/08/2011).

All data layers were loaded into a project in ArcGIS/ArcMap 10 (ESRI), allowing for visual spatial interpretation of the distribution of species in relation to the three major road segments that are the focus of the study. In addition to visual analysis, the following statistics were calculated: the mean center of the distribution of absolute location points in order to compare it to the centroid of the Legal Amazon of Brazil. Buffers of $100 \mathrm{~km}$ were drawn around each road segment, based on an understanding that road impacts can extend $100 \mathrm{~km}$ on either side of a major highway in the region [24]. Each buffer was used to clip the absolute locations of species occurrences and conservation units (hereafter by the Portuguese acronym "UC") and indigenous lands (hereafter by the Portuguese acronym "TI") areas within the buffer, allowing for more focused analysis of the road segments: percent of buffer area covered by UCs and TIs, number of absolute locations, and species richness.

\section{Results}

\subsection{Diversity and Distribution}

We obtained 14,096 records of orchid bees collected in Amazon basin during almost one hundred years, but only 14,070 could be georeferenced. We obtained 96 species (Table 1) from 882 collection places (Table 2), well distributed across 
the Brazilian Amazon, but not uniformly (Figure 1). The mean center of the absolute locations is approximately $350 \mathrm{~km}$ to the northwest of the centroid of the Legal Amazon, indicating a slight bias in spatial coverage in that direction (Figure 1). We discovered that from 473 collection places (c. 54\%) we know about the presence of just one species of bee, and from 352 (c. 39\%) there are only 2 to 10 species recorded (Table 2). Thirteen species were found only once, each at their own unique location (from Eufriesea bare to Euglossapolita). There are very large areas without any records in Western Roraima (RR), Western Amapá (AP), Northern and Southern Pará (PA), Northwest and Southern Amazonas (AM), Central Acre (AC) in the valley of the Feijó and Tarauacá rivers, and in practically all of Mato Grosso (MT) and Tocantins (TO) and Southwestern Maranhão(MA) (Figure 1).

Only 21 collection places $(2.4 \%)$ of the 882 in this study are situated in conservation units (Figures 2-5), which corresponds to only 1077 (7.64\%) of all records. This is a very small amount, considering that the Brazilian Amazon hosts more than 300 conservation units: 307 in [9] and 315 in [27].

\subsection{Highway-Level Results}

BR 319-Manaus-Porto Velho (Concluded in 1973). Of the three highway stretches analyzed, this had by far the largest number of collections places (125) sampled within its $100 \mathrm{~km}$ buffer for the five existent genera and here studied: Aglae, Exaerete, Eufriesea, Euglossa (with 5 subgenera) and Eulaema (with two subgenera) (Figure 1 and Figures 2-5, and Table 3), with locations distributed along both sides, by the Madeira and Purus rivers that run parallel to the highway. It also has the greatest known diversity (46 species). The central area of this highway has a reasonable number of records, and it is relatively well covered on both sides by protected areas that were created in 2006 by the following conservation units: The RDS (Sustainable Use Reserve) Igapó-Açu, the RDS Rio Amapá, the RESEX (Extractive Reserve) do Lago do Capana Grande, the FLOREST (State Forest) de Tapauá, the FLONA (National Forest) Balata-Tufari and the PARNA (National Park) Nascentes do Lago Jari. 51.15\% of the $100 \mathrm{~km}$ buffer area around this stretch of highway is in some form of protected area. The southern third, however, needs more attention on the west up to the border with Rondônia, while the northern third, beyond Careiro da Várzea, remains one of the least protected areas. Both of these regions have few records.

BR 230-Itaituba-Marabá (Concluded in 1972) [28]. The area within the 100 $\mathrm{km}$ buffer of this road segment is strongly lacking in orchid bee records ( 23 collection places) (Figure 1) for the five genera (Figures 2-5, and Table 3), and not surprisingly only 18 species are recorded there. The situation of the BR 230 is quite critical concerning protected areas, with only $38.9 \%$ of the buffer area under protected status; only three small protected areas exist within the southern portion: the APA (Environmental Protected Area) do Lago de Tucuruí, the RDS Alcobaça and the RDS Tucuruí-Ararão, near Marabá, and in addition the TI (Indigenous Land) Arara, situated between Itaituba and Altamira, and the TI 
Table 1. Species of orchid bees, number of individuals and collection locations in the Brazilian Amazon.

\begin{tabular}{|c|c|c|}
\hline Species & $\begin{array}{l}\text { Number of } \\
\text { specimens }\end{array}$ & $\begin{array}{c}\text { Number of places } \\
\text { of collection }\end{array}$ \\
\hline Eufriesea bare Gonzales \& Gaiani, 1989 & 1 & 1 \\
\hline Eufriesea chrysopyga (Mocsáry, 1896) & 1 & 1 \\
\hline Eufriesea distinguenda (Gribodo, 1882) & 1 & 1 \\
\hline Eufriesea nigrescens (Friese, 1923) & 1 & 1 \\
\hline Eufriesea pallida (Kimsey, 1977) & 1 & 1 \\
\hline Eufriesea smaragdina (Perty, 1833) & 1 & 1 \\
\hline Eufriesea violascens (Mocsary, 1898) & 1 & 1 \\
\hline Euglossa (Euglossa) aureiventris (Friese, 1899) & 1 & 1 \\
\hline Euglossa (Euglossa) deceptrix (Moure, 1968) & 1 & 1 \\
\hline Euglossa (subgênero?) lazulina (Friese, 1923) & 1 & 1 \\
\hline Euglossa (Euglossella) perfulgens (Moure, 1967) & 1 & 1 \\
\hline Euglossa (Euglossella) perviridis (Dressler, 1985) & 1 & 1 \\
\hline Euglossa (Euglossella) polita (Ducke, 1902) & 1 & 1 \\
\hline Euglossa (Glossuropoda) juremae (Moure, 1989) & 2 & 2 \\
\hline Euglossa (Euglossa) townsendi (Ducke, 1902) & 2 & 1 \\
\hline Eufriesea violacea (Blanchard, 1840) & 2 & 2 \\
\hline Euglossa (Euglossa) fimbriata (Rebelo \& Moure, 1995) & 2 & 2 \\
\hline Euglossa (Glossuropoda) hugonis (Moure, 1989) & 3 & 3 \\
\hline Euglossa (Glossuropoda) rugilabris (Moure, 1967) & 3 & 2 \\
\hline Eufriesea convexa (Friese, 1899) & 4 & 3 \\
\hline Eufriesea fuscatra (Moure, 1999) & 4 & 3 \\
\hline Euglossa (Euglossa) melanotricha (Moure, 1967) & 5 & 3 \\
\hline Eufriesea theresiae (Mocsary, 1908) & 5 & 4 \\
\hline Euglossa (Euglossa) violaceifrons (Rebelo \& Moure, 1995) & 5 & 5 \\
\hline Eufriesea fragocara (Kimsey, 1977) & 8 & 6 \\
\hline Euglossa (Euglossella) singularis (Mocsáry, 1899) & 9 & 6 \\
\hline Eufriesea concava (Friese, 1899) & 9 & 7 \\
\hline Eufriesea eburneocincta (Kimsey, 1977) & 13 & 8 \\
\hline Eufriesea formosa (Mocsary, 1908) & 14 & 8 \\
\hline Eulaema (Eulaema) peruviana (Friese, 1903) & 17 & 8 \\
\hline Eufriesea fallax (Smith, 1854) & 17 & 10 \\
\hline Eufriesea limbata (Mocsary, 1896) & 19 & 11 \\
\hline Eufriesea duckei (Friese, 1923) & 20 & 12 \\
\hline Euglossa (Euglossa) platymera (Dressler, 1982) & 20 & 12 \\
\hline Euglossa (Euglossa) retroviridis (Dressler, 1982) & 23 & 12 \\
\hline Euglossa chlorina (Dressler, 1982) & 23 & 16 \\
\hline Eufriesea laniventris (Ducke, 1902) & 25 & 17 \\
\hline Euglossa (Glossura) allosticta (Moure, 1969) & 25 & 17 \\
\hline Euglossa (Euglossa) ioprosopa (Dressler, 1982) & 31 & 18 \\
\hline
\end{tabular}




\section{Continued}

Eufriesea elegans (Lepeletier, 1841)

Euglossa (Glossura) viridifrons (Dressler, 1982)

Exaerete dentata (Linnaeus, 1758)

Aglae caerulea (Lepeletier \& Serville, 1825)

Eufriesea mussitans (Fabricius, 1787)

Euglossa (Euglossa) liopoda Dressler, 1982

Euglossa (Euglossa) pleosticta Dressler, 1982

Euglossa (Glossurella) prasina Dressler, 1982

Exaerete trochanterica (Friese, 1900)

Euglossa (Glossura) piliventris (Guerin, 1844)

Euglossa (Euglossa) magnipes (Dressler, 1982)

Euglossa (Euglossa) securigera (Dressler, 1982)

Eulaema (Eulaema) tenuifasciata (Friese, 1925)

Eufriesea auripes (Gribodo, 1882)

Euglossa (Euglossa) despecta (Moure, 1968)

Exaerete lepeletieri (Oliveira \& Nemésio, 2003)

Eufriesea flaviventris (Friese, 1899)

Eufriesea ornata (Mocsary, 1896)

Eufriesea superba (Hoffmannsegg, 1817)

Euglossa (Glossurella) stilbonota (Dressler, 1982)

Eufriesea vidua (Moure, 1976)

Euglossa (Glossurella) parvula (Dressler, 1982)

Euglossa (Euglossa) variabilis (Friese, 1899)

Euglossa (Euglossella) viridis (Perty, 1833)

Euglossa decorata (Smith, 1874)

Euglossa (Glossurella) crassipunctata (Moure, 1968)

Euglossa (Euglossa) analis (Westwood, 1840)

Euglossa (Glossurella) laevicincta (Dressler, 1982)

Euglossa (Glossura) orellana (Roubik, 2004)

Eulaema (Eulaema) polyzona (Mocsary, 1897)

Eufriesea surinamensis (Linnaeus, 1758)

Eufriesea purpurata (Mocsary, 1896)

Euglossa (Euglossa) bidentata (Dressler, 1982)

Euglossa (Euglossa) iopyrrha (Dressler, 1982)

Euglossa (Euglossa) amazonica (Dressler, 1982)

Euglossa (Glossurella) augaspis (Dressler, 1982)

Euglossa (Euglossa) cordata (Linnaeus, 1758)

Euglossa (Euglossa) mourei (Dressler, 1982)

Euglossa (Glossuropoda) intersecta (Latreille, 1938)

Euglossa (Euglossa) mixta (Friese, 1899) 


\section{Continued}

\begin{tabular}{ccc}
\hline Eulaema (Apeulaema) pseudocingulata (Oliveira, 2006) & 287 & 91 \\
Euglossa (Euglossa) modestior (Dressler, 1982) & 290 & 101 \\
Euglossa (Euglossa) avicula (Dressler, 1982) & 332 & 113 \\
Euglossa (Euglossa) gaianii (Dressler, 1982) & 341 & 114 \\
Euglossa (Euglossa) sp. $\mathrm{n}$. & 351 & 115 \\
Exaerete frontalis (Guérin, 1845) & 351 & 115 \\
Euglossa (Euglossa) cognata (Moure, 1970) & 363 & 131 \\
Eufriesea pulchra (Smith, 1854) & 368 & 137 \\
Exaerete smaragdina (Guérin, 1845) & 433 & 147 \\
Eulaema (Apeulaema) nigrita (Lepeletier, 1841) & 448 & 150 \\
Euglossa chalybeata (Friese, 1925) & 485 & 158 \\
Euglossa (Glossura) ignita Smith, 1874 & 737 & 195 \\
Eulaema (Apeulaema) mocsaryi (Friese, 1899) & 972 & 205 \\
Eulaema (Apeulaema) cingulata (Fabricius, 1804) & 1022 & 230 \\
Eulaema (Eulaema) bombiformis (Packard, 1869) & 1458 & 283 \\
Eulaema (Eulaema) meriana (Olivier, 1789) & 1602 & 364 \\
Total & 14,097 &
\end{tabular}

Table 2. Number of species of orchid bees collected according to number of collection places in Brazilian Amazon.

\begin{tabular}{cc}
\hline Number of species & Number of collection places \\
\hline 1 & 473 \\
$2-10$ & 352 \\
$11-20$ & 53 \\
$21-29$ & 4 \\
Total & $\mathbf{8 8 2}$ \\
\hline
\end{tabular}

Table 3. Summary statistics from the highway-level analysis, considering the area contained within a $100 \mathrm{~km}$ buffer of the road segment.

\begin{tabular}{cccc}
\hline & BR-319 & BR-230 & BR-163 \\
\hline Area of 100 km buffer $\left(\mathrm{km}^{2}\right)$ & 197,403 & 254,986 & 326,514 \\
Species richness & 46 & 18 & 23 \\
No. collection places & 125 & 23 & 30 \\
Area of UC $\left(\mathrm{km}^{2}\right)$ & 76,713 & 77,364 & 55,765 \\
Area of TI $\left(\mathrm{km}^{2}\right)$ & 24,902 & 21,929 & 31,751 \\
Percent of buffer protected & $51.5 \%$ & $38.9 \%$ & $26.8 \%$ \\
\hline
\end{tabular}

Parakanã situated between this last city and Marabá.

BR 163-Cuiabá-Santarém (Concluded in 1973). This highway segment was the largest stretch of road studied, but it had only several more records and species 


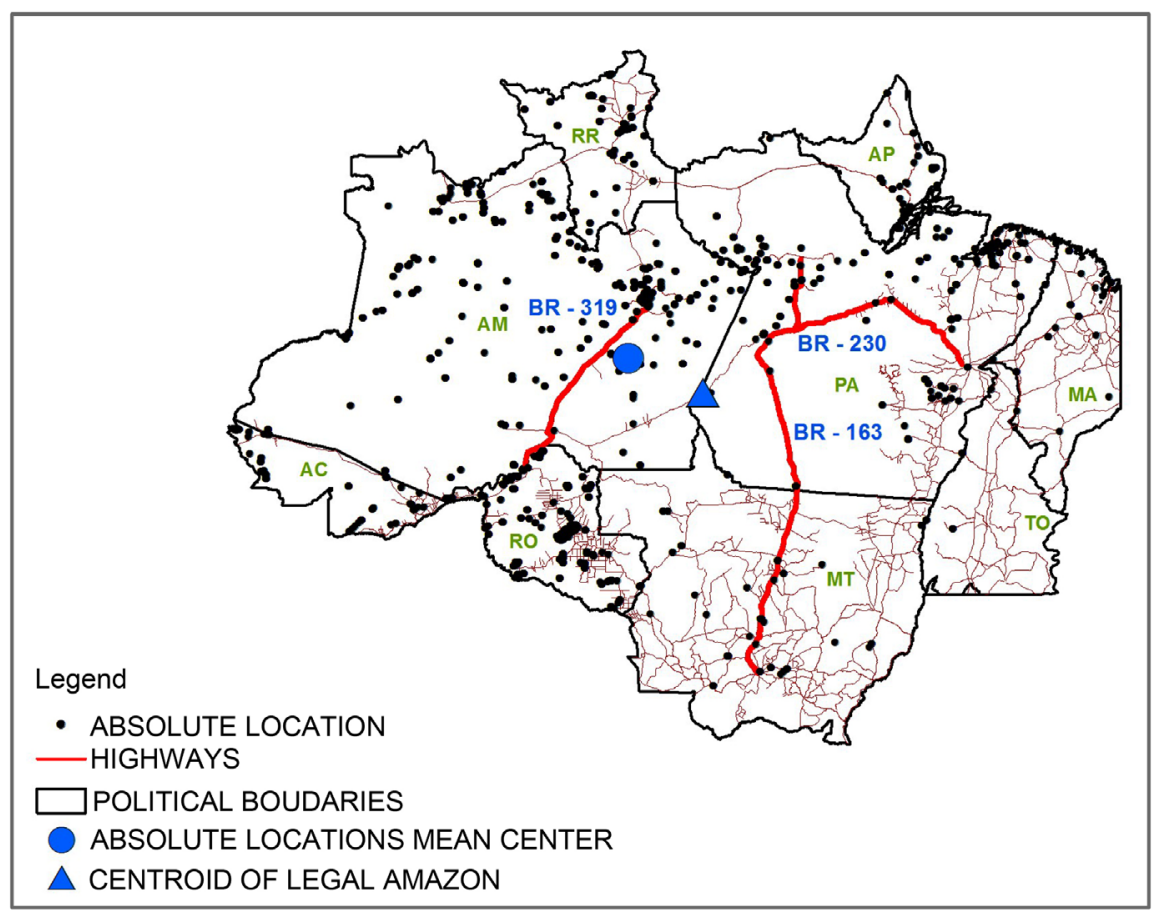

Figure 1. Collection places of orchid bees in the Brazilian Amazon (dark circles) and highways that are being reconstructed as part of the PAC-Plan for Growth Acceleration: BR 230 or the Transamazon (Itaituba-Marabá), BR 319 (Manaus-Porto Velho) and BR 163 (Cuiabá-Santarém) (in dark red). The mean center of absolute locations (blue dot) and the centroid of the Legal Amazon are also marked (blue triangle). Black lines are political boundaries.

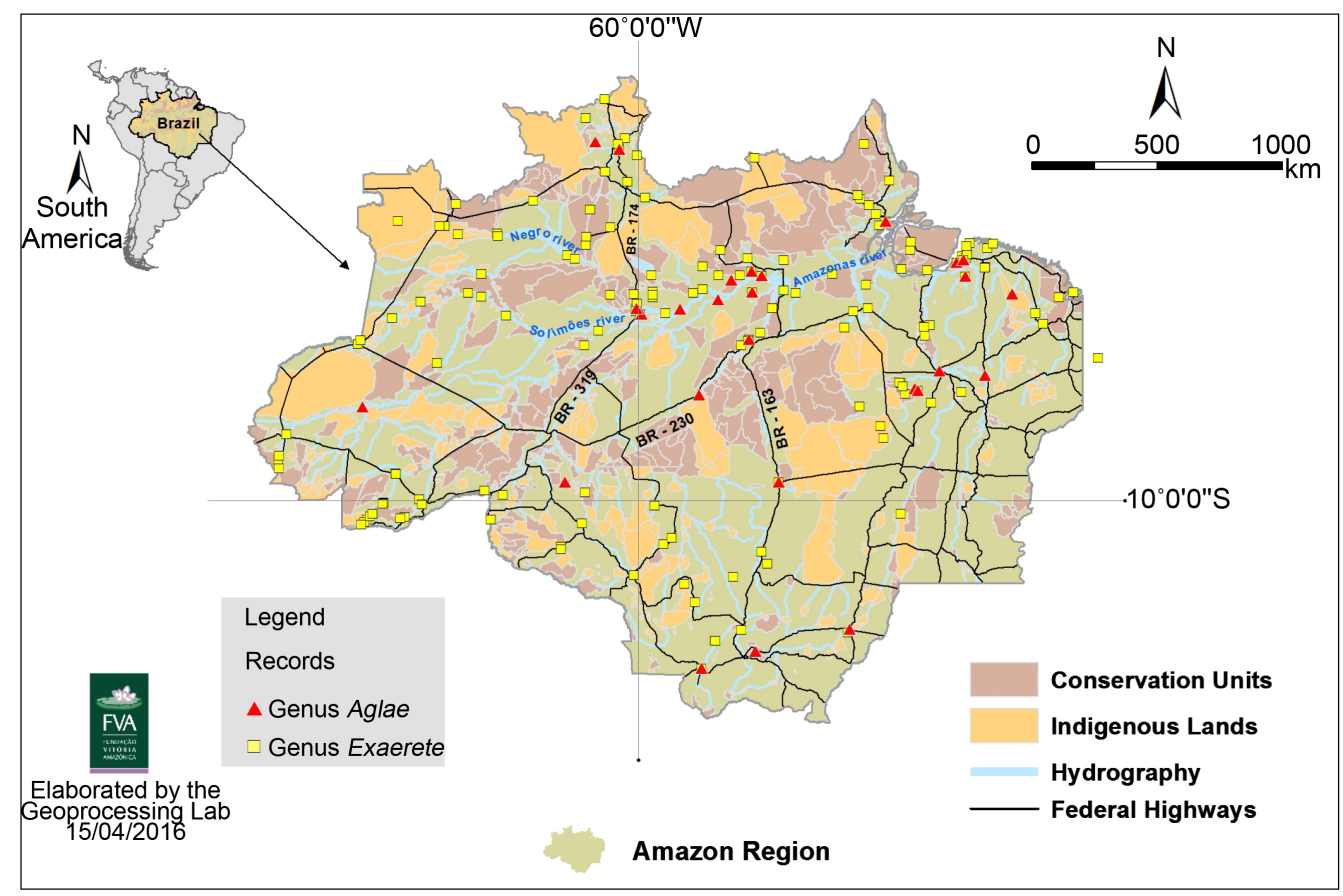

Figure 2. Collection places of orchid bees of the genera Aglae (red triangles) and Exaerete (yellow squares) in the Brazilian Amazon, Conservation Units (brown), Indigenous Lands (ochre) and the three highways that are being improved by the PAC-Plan for Growth Acceleration: BR 230 or the Transamazon (Itaituba-Marabá), BR 319 (Manaus-Porto Velho) and BR 163 (Cuiabá-Santarém). 


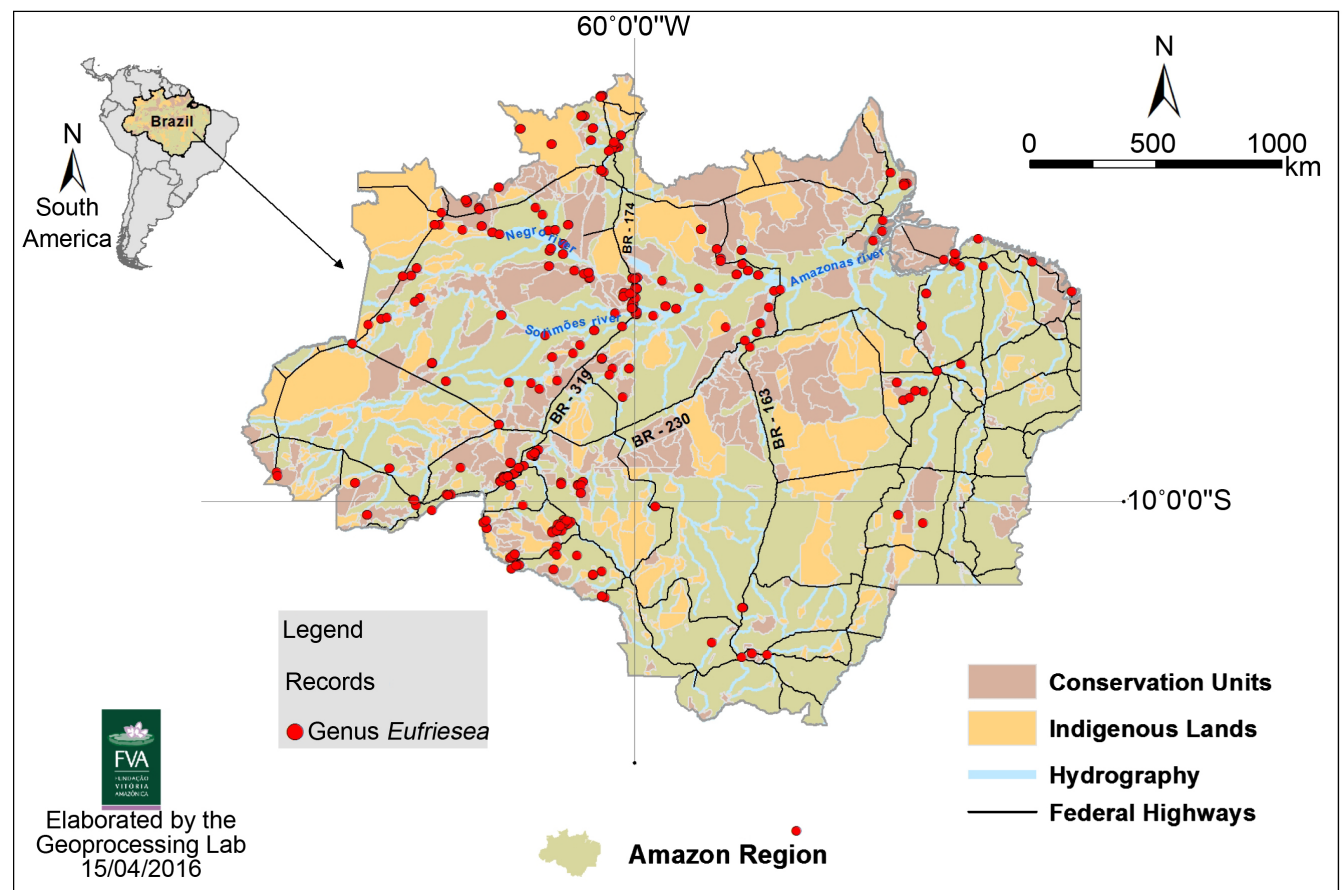

Figure 3. Collection places of orchid bees of the genus Eufriesea (red circles) in the Brazilian Amazon, Conservation Units (brown), Indigenous Lands (ochre) and the three highways that have been reconstructed by the PAC-Plan for Growth Acceleration: BR 230 or the Transamazon (Itaituba-Marabá), BR 319 (Manaus-Porto Velho) and BR 163 (Cuiabá-Santarém).

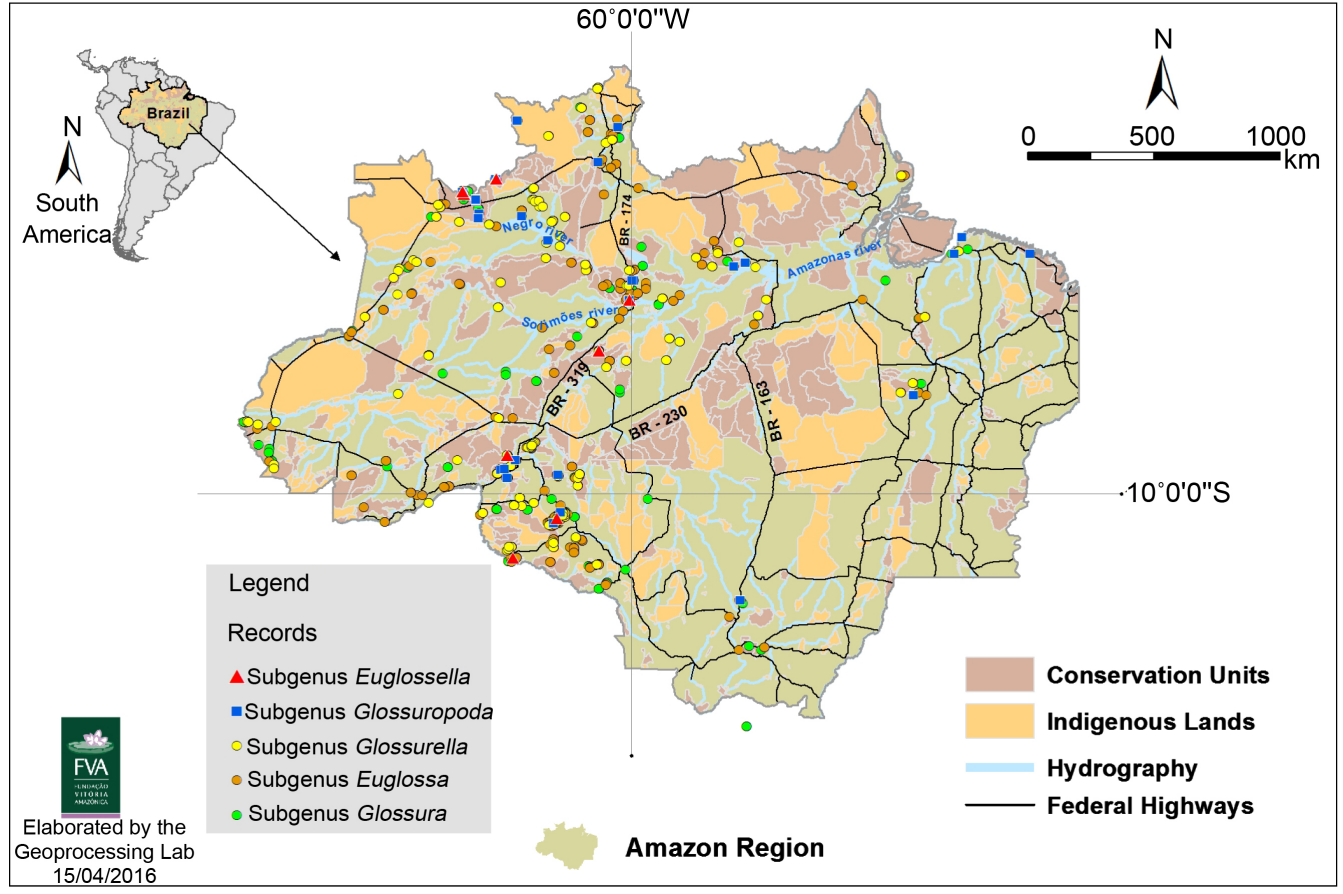

Figure 4. Collection places of orchid bees of the five subgenera of Euglossa in the Brazilian Amazon: $E$. (Euglossella) (red triangles), E. (Glossuropoda) (blue squares), E. (Glossurella) (yellow circles), E. (Euglossa) (brown circles), and E. (Glossura) (green circles). Conservation Units (brown), Indigenous Lands (ochre) and the three highways that have been reconstructed by the PAC-Plan for Growth Acceleration: BR 230 or the Transamazon (Itaituba-Marabá), BR 319 (Manaus-Porto Velho) and BR 163 (Cuiabá-Santarém). 


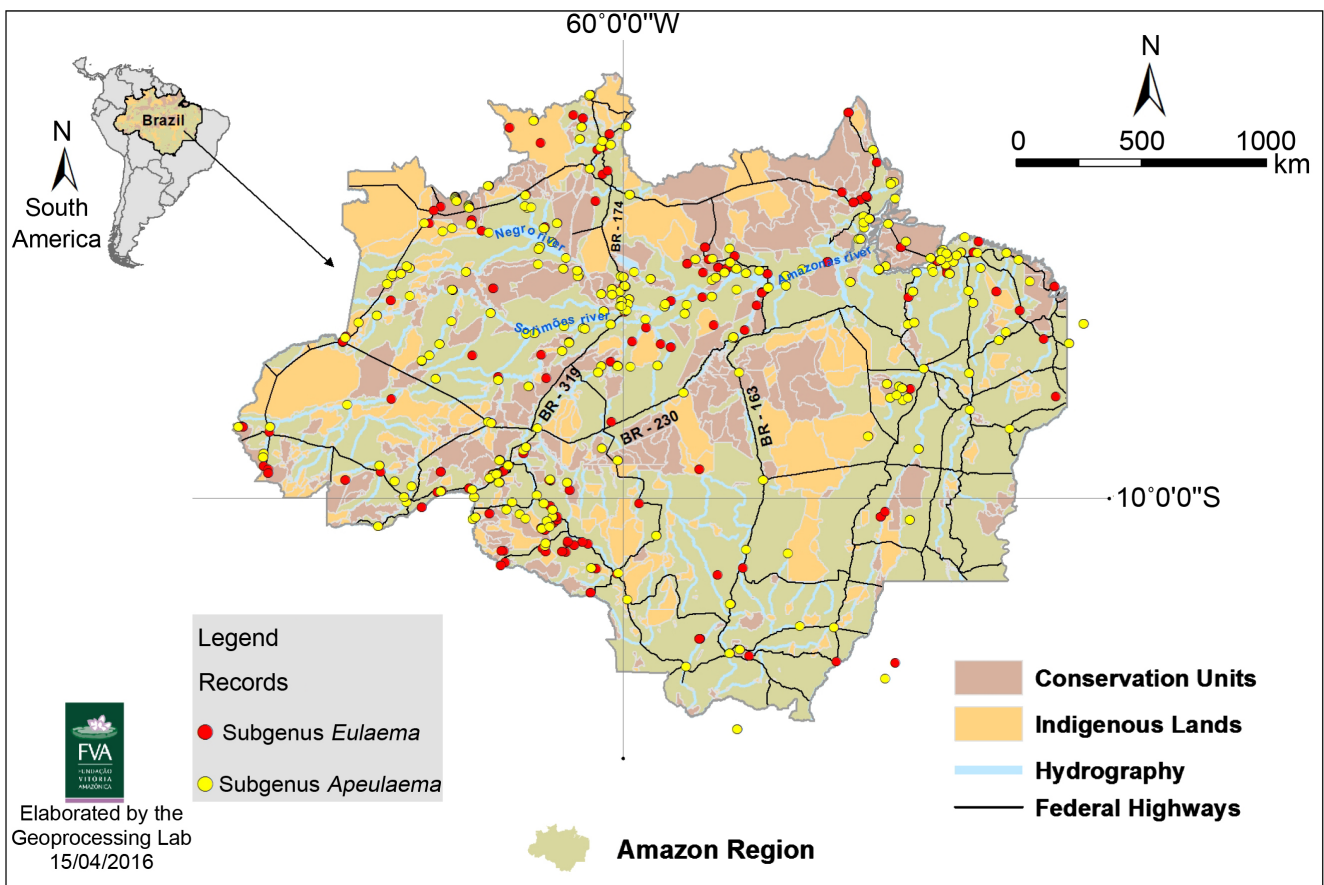

Figure 5. Collection places of orchid bees of the two subgenera of Eulaema in the Brazilian Amazon: $E$. (Eulaema) (red circles) and E. (Apeulaema) (yellow circles). Conservation Units (brown), Indigenous Lands (ochre) and the three highways that have been reconstructed by the PAC-Plan for Growth Acceleration: BR 230 or the Transamazon (Itaituba-Marabá), BR 319 (Manaus-Porto Velho) and BR 163 (Cuiabá-Santarém).

than the BR-230 (30 collection places, only 23 species) (Figure 1 and Figures 2-5 and Table 3), and it is the least served by protected areas (26.8\% of the buffer area). Over its long run from Cuiabá, Mato Grosso to the border with Pará we have extremely few records. In the south of Pará the road is tangent to the REBIO (Biological Reserve) Nascentes da Serra do Cachimbo, to the east; it then cuts through a large area without any protected areas and later passes through the middle of the Jamanxim National Park, which is surrounded by various sustainable use areas. Finally, near Santarém, the road runs along the Tapajós National Forest to the west. Along this final stretch we have a few more records on the western side, thanks to some collections that have been done in the lower Tapajósriver.

\section{Discussion}

This is perhaps one of the greatest efforts to locate the records of every specimen of an insect taxa and map collection locations in the Brazilian Amazon, but it likely presents a picture that is not much different than what we would get from a similar exercise done for other taxonomic groups. Collections are concentrated along the main rivers and around the region's major cities, while extensive areas remain under-sampled or un-sampled [29] [30] [31]. Moreover, the majority of the locations sampled do not represent complete inventories; they are merely casual collections. A similar situation occurs with birds, perhaps one of the most studied groups in Amazonia. Oren [31], for example, notes how difficult it is to 
establish priority areas for conservation based on such incomplete information. This picture shows how ease of access often dictates collection locations more than biogeographic or ecological criteria.

The case of the thirteen species collected only once, each in its own unique location, suggests that such species have very restricted geographic distributions; from the point of view of conservation, this has serious implications. The same can be said for the plants these species pollinate. This makes is even more critical if we take into account the scenario brought by major improvements of highways in the Amazon together with the absence of a wider safety net of conservation units and indigenous lands. Taken as a whole, these species are left in a vulnerable position. Feeley \& Silman [32] analyzed a database containing 800,000 georeferenced records of tropical vascular plants for use in niche or habitat modeling, tools commonly used to predict species responses to climate change. They found that close to nine out of every ten species have been poorly collected ( $\mathrm{n}<20$ records), making them practically invisible to niche modeling tools aimed at promoting their conservation. If we adopt the same criteria, we see that close to 4 out of 10 orchid bee species have less than 20 records.

The need to sample in the states with scarce records, such as in Tocantins, Maranhão and Mato Grosso, for example, is made ever more urgent, considering that there are so few conservation areas (Figures 2-5) and that natural vegetation in those states is also disappearing in recent years (Figure 6).

Of the areas influenced by the stretches of road specifically examined in this study, the BR-319 road segment area stands out as the most studied of the three highway areas. It has the largest number of collection locations and approximately

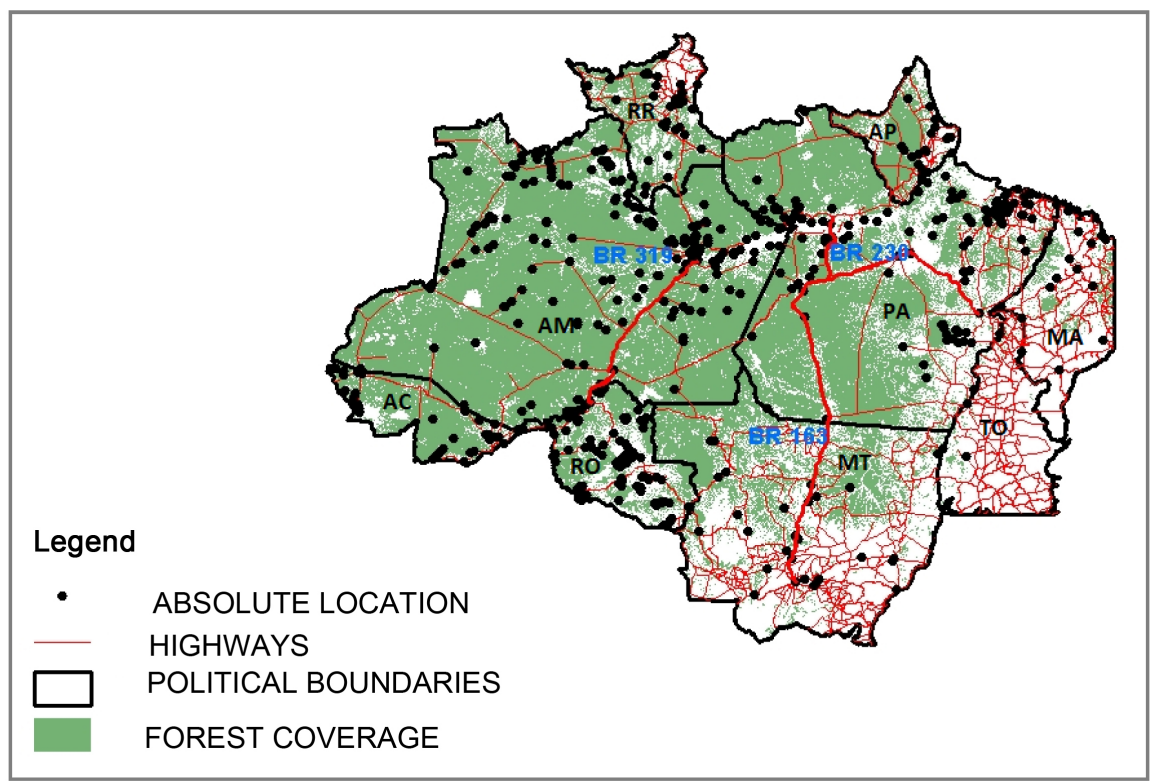

Figure 6. Collection places of orchid bees in the Brazilian Amazon (dark circles), forested area (green), non-forest vegetation (white) and highways that have been reconstructed by the PAC-Plan for Growth Acceleration: BR 230 or the Transamazon (Itaituba-Marabá), BR 319 (Manaus-Porto Velho) and BR 163 (Cuiabá-Santarém) (in dark red). Black lines are political boundaries. 
twice the species diversity of the other areas. It is also relatively well protected by UCs and TIs, in comparison to the other areas. In sharp contrast, the BR-163 stands out as covering the largest area, with the least effort expended thus far to study biodiversity, given its size. It has a low percentage of its area of influence protected by UCs or TIs as well. The BR-230 segment is also covered poorly with collections, but it has a slightly higher percent of its area of influence covered by protected areas. Based on this, we recommend that collecting efforts be focused on both of these latter stretches of road, before any further developments occur, in the hopes that we may discover more species before they become extinct. To conserve existing biodiversity in these areas, it is important to consider the establishment of new UCs or TIs, especially along the BR-163. This stretch of road is very likely to become a major thoroughfare of export of soybeans from the main growing areas of central Mato Grosso state north to a port in Santarém, on the Amazon River. Recent political developments in Brazil (mid-year, 2016) have placed Blairo Maggi as the Minister of Agriculture. This former senator and governor of Mato Grosso state is also one of the world's largest producers of soybeans, and he has also called for changes in regulations to make it easier and quicker to develop infrastructure in the Amazon, without the need to follow current environmental impact statement procedures. He also wants to make it possible to produce soybeans and other commodities within indigenous lands, putting in question the value indigenous lands have for conservation [33].

Borges \& Ferreira [34], Borges et al. [35], Ferreira et al. [16], and Nepstad et al. [36] and all claim that even by being designated conservation units and indigenous lands help protect the forest. Based on this, these and other authors often suggest establishing conservation units along the roads of the Amazon, in the hopes of saving what remains of the biological resources in areas influenced by roads, as we also have recommended. In fact, this was made in BR 319 (ManausPorto Velho) and should be followed. It is important to remember, however, that these measures alone will not resolve the problem if they are not accompanied by public policies strongly grounded in an organized civil society. In Brazil, having an area designated as protected may in effect have little meaning. Besides the alarming lack of enforcement, in many cases laws are changed to reduce the size of protected areas or to allow roads to pass through them [37].

Even if we did have truly well protected conservation units and indigenous lands, our data raise some important additional concerns. Approximately $70 \%$ of collection places are located outside of protected areas. Conservation units, making up only $21 \%$ of collection places, thus may not be fulfilling their scientific research mission, especially should the pattern we observed be repeated in other taxa. A few reasons may account for the low sampling in these areas. One is the bureaucracy researchers confront in simply getting permission to work in these areas. This makes budgeting and planning for field expeditions extremely difficult. There is also very little systematically assembled species inventories for Brazil's conservation units, making it difficult to plan which conservation units are in most need of biodiversity assessments. Inventories should be available for 
every conservation unit as a matter of practice. What one often gets from these conservation units is a short list of species names based on mere sightings or from talking with people who live in the area, especially hunters and fishers. Often, the information is restricted to vertebrates and flowering plants.

We have even less information from indigenous lands (only $9 \%$ of collection places). A major reason so little is known from these areas is, again, their relative inaccessibility to the scientific community. One of the aims of biological conservation is precisely to guarantee its proper use in these areas, but first we must understand what resources are there. FUNAI (Brazil's Federal Indian Affairs Bureau) and indigenous communities are concerned about the protection of traditional knowledge. This, unfortunately, has led to additional bureaucracy that makes it prohibitive for scientists to do research within indigenous lands. Scientists could play a role in documenting the biodiversity these areas protect, especially if such knowledge is important to the indigenous peoples, most of whom hunt and fish, in addition to other extractive activities. Better integration of activities between FUNAI, indigenous peoples, and centers of scientific research, might make it possible to both protect and learn more about the biological patrimony of these lands.

It is also important to recognize how important non-protected areas are potentially to our understanding of biodiversity and its protection [38]. These areas, after all, are where we have the most information about the taxa in question and where it is easiest to carry out future collections. The key is to implement ways to maintain as much habitat as possible to maintain species populations and to maximize contact among metapopulations among orchid bees and other pollinators in general. Thus, we strongly advocate for policies that incentivize keeping as many abandoned fields and pastures in fallow. As they undergo secondary succession, they would become what beekeepers in Brazil call pastosujo, or "dirty" pasture. With the large amount of weeds entering these areas, they become excellent resources for bees and other pollinators. In most cases, conservation units and indigenous lands are situated distant from highways, and so incentivizing the regrowth of forests in strategic areas could both create buffer areas between the highways and protected areas and help establish ecological corridors linking protected areas.

In the end it is difficult to know with certainty what the federal government is planning concerning the opening and reconstruction of highways in the Amazon. The same is true for state governments. On the website of the Ministry of Transport, we found various maps leading observers to believe that a number of new highway building and reconstruction scenarios are possible. Our attention was especially drawn to one of the maps of the Brazilian Amazon, showing a large number of roads designated as "planned" to Acre state, as well as to other states. Greater interaction and dialogue between Brazilian agencies responsible for road development and conservation could lead to initiatives that seek to achieve both in a more rational manner. 


\section{Acknowledgements}

Oliveira recognizes the support of CNPq (Brazilian National Council of Researches) project \#200698/2010-9. The present work was supported by CNPq (process \#306100/2016-9). Thanks to Vijay Barve, Chris Bishop, Charles Michener (in memoriam), Ismael Hinojosa-Dias, Jenifer Thomas, Brian Harris, Silvia Pedro, José Amílcar, Gabriel Melo, Yasmine Antonini, Orlando Silveira, Breno Y. Azevedo, Danielle Storck-Tonon, Elder Morato, Sílvio Silva, Marcela Monné, Alexandre Ururahy, Rodrigo Barbosa, Danielle Cerri, Jane Costa, Margarita Lopez-Uribe, Sérgio Borges and Kátia Lenz (Marcio's wife, in memoriam). Brown recognizes the support of the College of Liberal Arts and Sciences, the Fulbright Commission, and the FAPESP 2015/19437-5 (São Paulo Research Foundation).

\section{References}

[1] Meye, C., Kreft, H., Guralnick, R. and Jetz, W. (2015) Global Priorities for an Effective Information Basis of Biodiversity Distributions. Nature Communications, 68221.

[2] Sousa-Baena, M.S., Garcia, L.C. and Peterson, A.T. (2014) Completeness of Digital Accessible Knowledge of the Plants of Brazil and Priorities for Survey and Inventory. Diversity and Distributions, 20, 369-381. https://doi.org/10.1111/ddi.12136

[3] Garófalo, C.A. (2009) Patrimônio não avaliado. Scientific American (Brasi), 7, 50-51.

[4] Oliveira, M.L. (2015) Apidae, Andrenidae, Colletidae, Halicitidae e Megachilidae. In: Boeger, W.A., Hussam, Z., Rafael, J.A. and Valim, M.P., Orgs., Catálogo Taxonômico da Fauna do Brasil.

http://fauna.jbrj.gov.br/fauna/listaBrasil/ConsultaPublicaUC/ConsultaPublicaUC.do

[5] Roubik, D.W. and Hanson, P.E. (2004) Abejas de orquídeas de la America tropical. INBio Santo Domingo de Heredia, Costa Rica.

[6] Allen-Wardell, G., Bernhardt, P., Bitner, P., Burquez, A., Buchmann, S., Cane, J., Cox, P.A., Dalton, V., Feisinger, P., Ingram, M., Inouye, D., Jones, C.E., Kennedy, K., Kevan, P., Koopowitz, H., Medellin-Morales, S. and Nabhan, G.P. (1998) The Potential Consequences of Pollinator Decline on the Biodiversity and Stability of Food Crop Yields. Conservation Biology, 12, 8-17. https://doi.org/10.1111/j.1523-1739.1998.97154.x

[7] Brown, J.C. and Albrecht, C. (2001) The Effect of Tropical Deforestation on Stingless Bees of the Genus Melipona (Insecta: Hymenoptera: Apidae: Meliponini) in Central Rondônia, Brazil. Journal of Biogeography, 28, 623-634.

https://doi.org/10.1046/j.1365-2699.2001.00583.x

[8] Brown, J.C. and Oliveira, M.L. (2014) The Impact of Colonization under Richness and Abundance of Stingless Bees in Rondônia, State, Brazil. Apidologie, 45, 172188. https://doi.org/10.1007/s13592-013-0236-3

[9] ARPA (2011) Áreas Protegidas na Amazônia Brasileira: Avanços e desafios. In; Veríssimo, A., Rolla, A., Vedoveto, M. and Futada, S.M., Orgs., Belém e ISA, IMAZON, São Paulo, maio ( $\left.n^{\circ} 1\right): 1-2$.

[10] Fearnside, P.M. (1991) Rondônia. Estradas que levam à devastação. CiênciaHoje. Volume Especial Amazônia, 116-122.

[11] Fearnside, P.M. (2006) Containing Destruction from Brazil's Amazon Highways: Now Is the Time to Give Weight to the Environment in Decision-Making. Environmental Conservation, 33, 181-183. https://doi.org/10.1017/S0376892906003109 
[12] Fearnside, P.M. (2007) Brazil's Cuiabá-Santarém (BR-163) Highway: The Environmental Cost of Paving a Soybean Corridor Through the Amazon. Environmental Management, 39, 601-614. https://doi.org/10.1007/s00267-006-0149-2

[13] Fearnside, P.M. (2008) Rodovia, ferrovia ou navios: A melhor ligação entre Manaus e SP. Jornal da Ciência (27 de junho de 2008), 10.

[14] Fearnside, P.M. (2012) A tomada de decisão sobre estradas amazônicas. In: Bager, A., Ed., Ecologia de Estradas, Tendências e Pesquisas, Editora UFLA, Lavras, 59-75.

[15] Fearnside, P.M. and Graça, P.M.L.A. (2006) BR-319: Brazil's Manaus-Porto Velho Highway and the Potential Impact of Linking the Arc of Deforestation to Central Amazonia. Environmental Management, 38, 705-716. https://doi.org/10.1007/s00267-005-0295-y

[16] Ferreira, L.V., Venticinque, E. and Almeida, S. (2005) O desmatamento na Amazônia e a importância das áreas protegidas. Estudos Avançados, 19, 157-166. https://doi.org/10.1590/S0103-40142005000100010

[17] Laurance, S.G.W., Stouffer, P.C. and Laurance, W.F. (2004) Effects of Road Clearings on Movement Patterns of Understory Rainforests Birds in Central Amazonia. Conservation Biology, 18, 1099-1109. https://doi.org/10.1111/j.1523-1739.2004.00268.x

[18] Laurance, W.F., Cochrane, M.A., Bergen, S., Fearnside, P.M., Delamônica, P., Barber, C., D'Angelo, S. and Fernandes, T. (2001) The Future of the Brazilian Amazon. Science, 291, 438-439. https://doi.org/10.1126/science.291.5503.438

[19] Moreira, M.P., Santos, C.J. and Ferreira, O.J.M.R. (2009) Desflorestamento ao longo das estradas AM-070 (Manaus/Iranduba/Manacapuru) e AM-352 (Manacapuru/ Novo Airão) na Amazônia Central: subsídios para o planejamento. Anais XIV Simpósio Brasileiro de Sensoriamento Remoto, Natal, Brasil, 25-30 Abril 2009, INPE, 747-754.

[20] Nepstad, D., Carvalho, G., Barros, A.C., Alencar, A., Capobianco, J.P., Bishop, J., Moutinho, P., Lefebvre, P., Silva Jr., U.L. and Prins, E. (2001) Road Paving, Fire Regime Feedbacks, and the Future of Amazon Forests. Forest Ecology and Management, 154, 395-407.

[21] Soares-Filho, B., Alencar, A., Nepstad, D., Cerqueira, D., Del Carmen, M., Diaz, M.C.V., Riveroz, S., Solórzano, L. and Voll, E. (2004) Simulating the Response of Land-Cover Changes to Road Paving and Governance along a Major Amazon Highway: The Santarém-Cuiabá Corridor. Global Change Biology, 10, 745-764. https://doi.org/10.1111/j.1529-8817.2003.00769.x

[22] Soares-Filho, B., Nepstad, D., Curran, L.M., Cerqueira, G.C., Garcia, R.A., Ramos, C.A., Voll, E., McDonald, A., Lefebvre, P. and Schlesinger, P. (2005) Modelling Conservation in the Amazon Basin. Nature, 440, 520-523. https://doi.org/10.1038/nature04389

[23] Souza Jr., C., Brandão Jr., A., Anderson, A. and Veríssimo, A. (2005) Avanço das Estradas Endógenas na Amazônia. O Estado da Amazônia.

[24] PAS (2004) Plano Amazônia Sustentável. Vol. 1. Diagnóstico e Estratégia. Ministério da Integração Nacional, Brasília.

[25] Ribeiro, J., Souza Jr., C. and Salomão, R. (2011) O impacto das estradas nas áreas protegidas. In: Veríssimo, A., Rolla, A., Vedoveto, M. anmd Futada, S.M., Orgs., ARPA-Áreas Protegidas na Amazônia Brasileira: Avanços e desafios, Imazon e Belém: ISA, São Paulo, 70-71.

[26] Dodson, C.H. and Frymire, G.P. (1961) Natural Pollination of Orchids. Annals of the Missouri Botanical Garden, 49, 133-152. 
[27] ISA-InstitutoSócio-Ambiental. https://uc.socioambiental.org/computos/amazonia-legal/biomas-bacias-hidrografica s-fitofisionomias

[28] Gomes, F.A. (1972) Transamazônica, a redescoberta do Brasil. Livraria Cultura Editora, São Paulo.

[29] Baccaro, F.B., Schietti, J., Guariento, H.F., Oliveira, M.L. and Magalhães, C. (2008) Avaliação de um patrimônio. Scientific American (Brasi), Especial Amazônia, 2, 24-29.

[30] Nelson, B.W., Ferreira, C.A.C., Silva, M.F. and Kawasaki, M.L. (1990) Endemism Centres, Refugia and Botanical Collection Density in Brazilian Amazonia. Nature, 345, 714-716. https://doi.org/10.1038/345714a0

[31] Oren, D. (2001) Biogeografia e conservação de aves na região amazônica. In: Capobianco, J.P., Veríssimo, A., Moreira, A., Sawyer, D., Santos, I. and Pinto, L.P., Orgs., Biodiversidade na Amazônia brasileira: Avaliação e ações prioritárias para a conservação, uso sustentável e repartição de benefícios, Estação da Liberdade e Instituto Socioambiental, São Paulo, 268-286.

[32] Feeley, K.J. and Silman, M.R. (2011) The Data Void in Modeling Current and Future Distributions of Tropical Species. Global Change Biology, 17, 626-630. https://doi.org/10.1111/j.1365-2486.2010.02239.x

[33] Phillips, D. and Miroff, N. (2016) Brazil Turmoil Looms over Amazon. Washington Post, 23 May 2016.

http://www.cortezjournal.com/article/20160523/AP/305239769/Brazilturmoillooms overAmazon

[34] Borges, C.A.R.F. and Ferreira, L.V. (2011) O processo de desflorestamento nas rodovias do estado do Pará: Um estudo de caso da rodovia Transamazônica (BR-230). Anais XV Simpósio Brasileiro de Sensoriamento Remoto-SBSR, Curitiba, PR, Brasil, 30 de abril a 05 de maio de 2011, INPE, 2796-2803.

[35] Borges, S.H., Iwanaga, S., Moreira, M.P. and Durigan, C.S. (2007) O desafio de proteger a Amazônia. Ciência Hoje, 41, 73-75.

[36] Nepstad, D., Schwartzman, S., Bamberger, B., Santilli, M., Ray, D., Schlesinger, P., Lefebvre, P., Alencar, A., Prinz, E., Fiske, G. and Rolla, A. (2006) Inhibition of Amazon Deforestation and Fire by Parks and Indigenous Lands. Conservation Biology, 20, 65-73. https://doi.org/10.1111/j.1523-1739.2006.00351.x

[37] Fearnside, P.M. (1989) A ocupação humana de Rondônia. Impactos, limites e planejamento. Programa Polonoroeste. Relatório de Pesquisas No. 5, SCT/PR.

[38] Perfecto, I., Vandermeer, J. and Wright, A. (2009) Nature's Matrix: Linking Agriculture, Conservation and Food Sovereignty. Earthscan, London. 
Submit or recommend next manuscript to SCIRP and we will provide best service for you:

Accepting pre-submission inquiries through Email, Facebook, LinkedIn, Twitter, etc. A wide selection of journals (inclusive of 9 subjects, more than 200 journals)

Providing 24-hour high-quality service

User-friendly online submission system

Fair and swift peer-review system

Efficient typesetting and proofreading procedure

Display of the result of downloads and visits, as well as the number of cited articles Maximum dissemination of your research work

Submit your manuscript at: http://papersubmission.scirp.org/

Or contact jep@scirp.org 